\title{
History of natural resource use and environmental impacts in an interfluvial upland forest area in western Amazonia
}

\author{
ANDERS SIREN
}

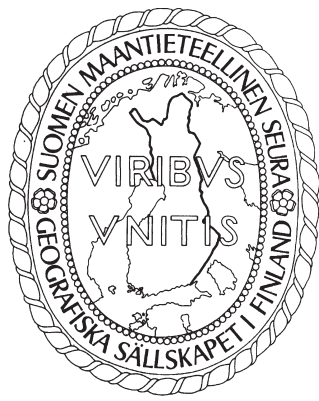

Siren, Anders (2014). History of natural resource use and environmental impacts in an interfluvial upland forest area in western Amazonia. Fennia 192: 1, pp. 36-53. ISSN 1798-5617.

Much of the research done on environmental impacts by Amazonian indigenous peoples in the past focus on certain areas where archaeological remains are particularly abundant, such as the Amazon River estuary, the seasonally inundated floodplain of the lower Amazon, and various sites in the forest-savannah mosaic of the southern Amazon. The environmental history of interfluvial upland areas has received less attention. This study reconstructed the history of human use of natural resources in an upland area of $1400 \mathrm{~km}^{2}$ surrounding the indigenous Kichwa community of Sarayaku in the Ecuadorian Amazon, based on oral history elicited from local elders as well as historical source documents and some modern scientific studies. Although data is scarce, one can conclude that the impacts of humans on the environment have varied in time and space in quite intricate ways. Hunting has affected, and continues affecting, basically the whole study area, but it is now more concentrated in space than what it has probably ever been before. Also forest clearing has become more concentrated in space but, in addition, it has gone from affecting only hilltops forests to affecting alluvial plains as well as hilltops and, lately, also the slopes of the hills.

Keywords: Amazonia; Ecuador; Environmental history; Forest clearing; Hunting; Indigenous peoples

Anders Siren, Division of Geography, P.O. Box 64, Fl-00014 University of Helsinki.E-mail: anders.siren@helsinki.fi

\section{Introduction}

To what extent the Amazonian forests are 'wilderness', and what legacies past generations of indigenous peoples have left on the forest ecosystem, are questions that have been intriguing researchers over the last few decades. Amazonian forests were long thought a pristine wilderness, but since the late 1980's a series of studies using a wide variety of approaches, including studies of historical source documents and archaeological artefacts, as well as biological methods based on dendrochronology and paleobotany, and even remote sensing, have challenged this view (e.g. Balée 1989, 1992; Denevan 1992; Gómez-Pompa \& Kaus 1992; Bush \& Colinvaux 1994; Cleary 2001; Pärssinen et al. 2009; Levis et al. 2012). Such studies have shown that forests that previously were thought to be pristine, in reality have been subject to disturbance and modifications by humans during thousands of years, leaving behind traces such as forests with elevated concentrations of useful tree species, earth works, and anthropogenic black-earth deposits. Such evidence led some authors to make quite radical conclusions, claiming that the Amazonian forests were 'anthropogenic' (Gómez-Pompa \& Kaus 1992) and that the idea of the forests of Amazonia being pristine was nothing but a 'myth' (Denevan 1992, 2011).

Other authors, however, argue that although there is evidence of heavy pre-Columbian human influence on the environment at certain sites, these sites are not representative of Amazonia as a whole. Such authors call for a more considered assessment of the spatial distribution of the ecological impacts of pre-Columbian peoples, and argue that most of Amazonia was sparsely populated and subject to relatively minor environmental impacts, as forest clearing and dispersal of useful plants affected only very limited areas, whereas the rest was subject only to the much milder impacts of hunting and gathering (Bush \& 
Silman 2007; Barlow et al. 2012; McMichael et al. 2012a, 2012b). Even though hunting and gathering obviously have much milder impacts than the outright removal of the entire forest cover, one should, however, be careful not to underestimate their potential ecological impacts. In many different ecosystems around the world, it has been shown that even harvest of just one or a few species may have cascade effects on entire ecosystems, and may have so even if harvest levels are relatively modest (Redford \& Feinsinger 2001; Milner-Gulland 2008; Salo et al. 2014: 225-241).

In tropical forests, a multitude of species are hunted, and many of them perform important functions as herbivores, seed predators and seed dispersers. Experimental studies and case studies in small areas indicate that hunting in tropical forests may harm recruitment of trees whose seeds are dispersed by large animals, and instead favor lianas and such trees whose seeds are dispersed by bats and wind (Stoner et al 2007; Wright et al. 2007; Terborgh et al. 2008). Although such studies often discuss the potential impacts current hunting may have on the future structure and composition of the forest, they much less often discuss the legacies that potentially may have already been left on the forest by millennia of hunting by humans in the past. An exception is Schüle (1992a, 1992b) who suggested that the closed forests of Amazonia as we know them today actually may be a result of Pleistocene overhunting that exterminated giant sloths and other megafaunal elements whose feeding kept the landscape relatively open. In spite of the potentially very important implications of this idea, these works have been relatively rarely cited - not even to put forward counterarguments - and have had little impact on conservation science and practice in neotropical rainforests.

The intensity of hunting is typically highly variable in space (Peres \& Lake 2003; Sirén et al. 2004), implying that areas near human settlements, roads, and navigable rivers, are currently subject to very intense impacts, whereas areas at a distance of above some 9-15 km from settlements and transport routes are almost unaffected by hunting. Any ecological legacies of hunting, in the form of changed species composition or structure of the forest, must, in the same manner, largely depend on the spatial patterns of hunting in the past, but this has rarely been examined.

Although the environmental impact caused by indigenous Amazonians in pre-Columbian times is an issue that has been intensively debated, it should not be forgotten that it is also highly relevant to study such impacts - or the absence thereof - after the arrival of Europeans to the continent. Writings on environmental history of Amazonia since the $16^{\text {th }}$ century tend, however, to focus narrowly on the impacts caused by nonindigenous settlers and 'western' society, particularly on areas subject to large-scale deforestation (e.g. Sponsel 1992), thus missing what has been going on in rest of Amazonia, where the environment has been subject to more subtle impacts, or even been recovering from previous impacts.

Much of the research done on environmental impacts by Amazonian and Neotropical indigenous peoples in the past focus on pre-Columbian times and on certain areas where archaeological remains are particularly abundant, such as the Yucatán (Foster \& Turner 2004), the Amazon River estuary (e.g. Roosevelt 1999), the seasonally inundated floodplain of the lower Amazon (e.g. Denevan 1996), and various sites in the forestsavannah mosaic of the southern Amazon (e.g. Balée 1989, 1992; Mayle et al. 2007). The environmental history of interfluvial upland areas, near the Andes Mountains, has received less attention. This research focuses on such an interfluvial upland area in western Amazonia, and primarily on post-Columbian times up to the turn of the millennium. The objective is to reconstruct, to the extent possible given the availability of data, the character, intensity, and spatial distribution of human impacts on the environment during the last five centuries.

This study responds, in two ways, to a call made for more attention to the spatial distribution of the ecological impacts of indigenous peoples (cf. Bush \& Silman 2007; Barlow et al. 2012; McMichael et al. 2012a, 2012b). First, the study area lies in a type of natural environment that has seldom been subject to this kind of study, and, second, the study itself has an explicitly spatial approach, focusing on how environmental impacts have been distributed in space within the study area. By providing historical depth as well as a view of the spatial variability of resource use in the particular area studied, this paper contributes to the ongoing quest for better understanding past interactions between humans and nature in Amazonia, including how human activities may have left lasting - although not always readily visible - traces on the forest composition. 


\section{Study area: The lands of the Sarayaku community}

Sarayaku is a community located along the middle stretches of the Bobonaza river, in the Pastaza province, in Ecuadorian Amazonia (Fig. 1). The nearest road is about $30 \mathrm{~km}$ upriver. The landscape consists of old fluvial deposits that have been uplifted by the eastward movement of the Andes and heavily dissected by erosion (Räsänen et al. 1990). Thus, the topography is rugged and characterized by ridges separated by deep valleys, where there typically are small creeks. The Bobonaza River is a sinous river running in the bottom of a confined valley. It has a winding course and stony rapids alternating with stretches of slow-flowing water. At most it reaches some forty meters width within the
Sarayaku lands. The surrounding alluvial plains occasionally get flooded for a day or two after heavy rains, but there is no seasonal flooding, so the forests on these plains are very distinct from the seasonally flooded varzea forests of lower Amazonia. Annual rainfall is about $3000-3500 \mathrm{~mm}$, and the elevation in the area is $330-640 \mathrm{~m}$ a. s. I. Natural environmental variability in the area has been discussed by Sirén et al. (2013).

A catholic mission was established at the site around 1830 (Jerves 1930; Espinosa 1943b) or possibly already in 1817 (Reeve 1988: 67). After this, various ethnic groups gradually merged in order to form what today is the Sarayaku kichwa. These groups were in particular the Záparo, from north of the Bobonaza River, the Achuar from the south, as well as some Kichwa-speaking Indians from Canelos, a mission $35 \mathrm{~km}$ upriver on the Bob-

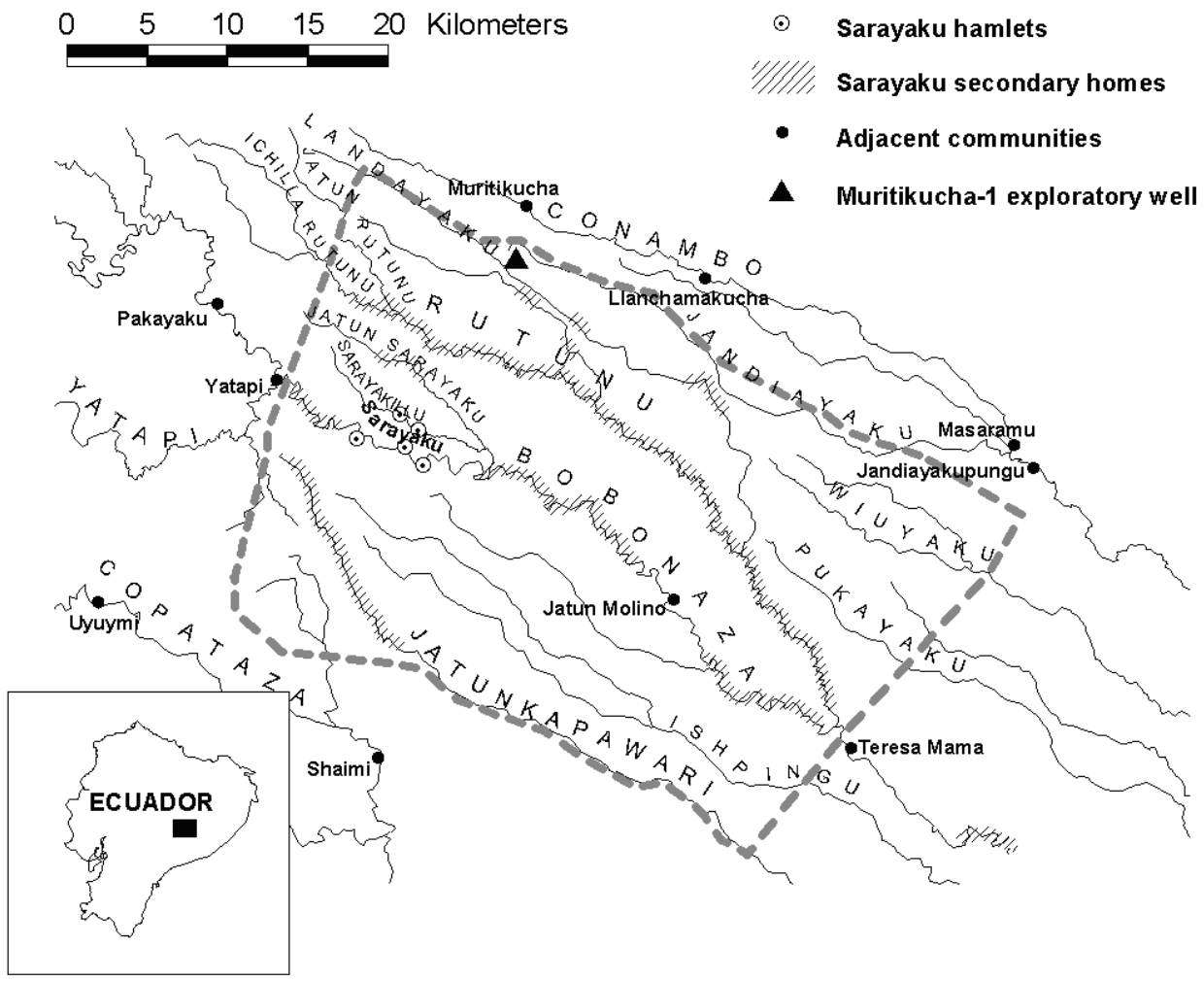

Fig. 1. Location of the study area. Dashed gray line indicates approximate limits of the study area. The history and current use of the secondary homes, or purinas, is further discussed in the text. 
onaza which had been established already in the 17 th century. The boom of collection of wild rubber in Amazonia, caused by the increased international demand, apparently reached Sarayaku in the late 1880's. Local elders tell that the rubber was shipped downriver to the city of Iquitos in Peru, and that this led to markedly increased economic and cultural interactions in downriver direction. It also led to further ethnic mixture, as mestizo rubber traders, Andoas Indians from downriver (currently Peru), as well as Napo Kichwa refugees fleeing from slavery-like debt bondage, arrived to Sarayaku, married and stayed.

Today Sarayaku has about a thousand inhabitants living in five separate hamlets, but during school vacations most families disperse out to secondary homes called purinas at some distance away from the main settlement (Fig. 1). Shifting cultivation, hunting, and fishing form the basis for what is largely a subsistence economy. Poultry is a minor complementary food source, and governmental salaries, cattle, fibers of the Aphandria natalia palm, handicrafts, tourism, and migratory work provide some cash income. Since 1992 Sarayaku and surrounding communities possess communal land titles, but the limits between communities are a desk product that neither reflects current land use, nor the previously existing customary or mutually agreed limits (Sawyer 1997; Sirén 2004: Ch. 5). The study area is defined as the area that the community currently claims as their property. This covers approximately $1400 \mathrm{~km}^{2}$, although the limits with adjacent communities are in many cases fuzzy or disputed.

In practice, the area used exclusively by people from Sarayaku decreased during the $20^{\text {th }}$ century, as several new communities were established within or on the fringes of Sarayaku lands, starting around 1960. At that time, the Shaimi village was formed by dispersed groups of Achuar who settled down to live in a permanent village, the Teresa Mama village was formed by a family from Sarayaku who settled permanently in their secondary home and got many children, whereas the villages of Yatapi and Muritikucha were formed mainly by people from nearby communities. In 1983, about a tenth of the Sarayaku households left to create a new community called Jatun Molino some $15 \mathrm{~km}$ downstream of Sarayaku, since then forming an enclave within Sarayaku lands. In the 1990's a few families budded off from the Llanchamakucha community to form a new community called Masaramu. Although there were no fixed limits be- tween communities, in practice the foundation of all these new villages (Fig. 1) implied a reduction in the area available for the Sarayaku people.

The direct impact of the Sarayaku people on the forest cover is modest; about $0.2 \%$ of the study area is under current cultivation, and about $4 \%$ consists of fallows younger than 65 years (Sirén 2007). On the other hand, practically the whole area suffers an impact from hunting. In particular, spider monkey (Ateles belzebuth), woolly monkey (Lagothrix lagotricha and L. poeppigii), tapir (Tapirus terrestris) and Salvin's currassow (Mitu salvini) are severely depleted and even locally extinct over a large part of the community's hunting grounds, and also several other species have strongly reduced populations (Sirén et al. 2004).

\section{Methods}

This study is largely based on information provided by local people (For similar approaches to the study of the history of Amazonian peoples see Muratorio 1991, Cabodevilla 1999, and Stanfield 1998), but also draws on historical source documents, grey literature, and scientific publications. In the first place, the study relies on compilation, i.e. the accumulation of data and information from written or oral, primary or secondary sources, specifically about the study area. When information about the study area itself has not been available, the study instead relies on extrapolation in space and time, assuming that the study area has undergone similar change processes as other similar areas have done. Such extrapolation is risky, as one easily may underestimate the ecological and cultural variability in Amazonia and make too sweeping generalizations. Therefore, such extrapolation was made based only on information about areas near the study area and known to be similar to it, culturally as well as ecologically. When neither compilation nor extrapolation was possible, instead deduction was used, i.e. logical reasoning based on known principles about the relations between humans and the environment.

In order to record oral history a number of workshops were organized with local community members. During a first workshop, a historical line was constructed, which identified, and located in time, the main historical events recognized by the community members. Based on this, eight distinct epochs were defined (Table 1), which formed the basis for the subsequent group interviews. 
Table 1. Major events in the history of the community which were used in order to structure discussions at workshops with local elders.

\begin{tabular}{|c|c|c|}
\hline Event & Year & Comments \\
\hline $\begin{array}{l}\text { First arrival of } \\
\text { missionaries }\end{array}$ & $1817-1833$ & $\begin{array}{l}\text { The mission was abandoned in } 1867 \text { and re-established four or five years } \\
\text { later (Pierre 1983: 8, 99). Some accounts by the elders about the arrival of } \\
\text { the missionaries seem to refer to that re-establishment of the mission in the } \\
1870 \text { 's. }\end{array}$ \\
\hline $\begin{array}{l}\text { Onset of the rubber } \\
\text { boom }\end{array}$ & $1887-1890$ & $\begin{array}{l}\text { An exhaustive traveler's account from Sarayaku in } 1887 \text { makes no mention } \\
\text { of any rubber trade going on (Pierre 1983: 175-182), but another account } \\
\text { only three years later mentions an intense activity of collecting and trading } \\
\text { rubber (Vargas 1976: 44, 82). }\end{array}$ \\
\hline $\begin{array}{l}\text { Demise of the rubber } \\
\text { boom }\end{array}$ & $\begin{array}{l}\text { Approx. } \\
1910-1920\end{array}$ & $\begin{array}{l}\text { No elders had own memories of the rubber boom going on, and the oldest } \\
\text { were born around } 1920 \text {. There was a short resurgence of rubber trade in the } \\
1940 \text { 's, and some elders seemed to refer to this epoch instead, when talking } \\
\text { about the rubber boom. }\end{array}$ \\
\hline
\end{tabular}

Beginning of war between Ecuador and

Peru

Arrival of Protestant missionaries born, or not born, at the time.

Creation of Centro

Alama Sarayacu, the first community organization

Footmarch to Quito in order to demand land titles

\section{2}

Group interviews had a semi-structured character and were based on a scheme where a list of questions had been defined for each one out of six broad themes, namely 1) Demography and settlement pattern, 2) Agriculture and domestic animals, 3) Hunting, 4) Fishing, 5) Trade, and finally, 6) Social organization and power relations. Although the focus of this article corresponds primarily to the three first of these themes, also the other three themes were important in order to get a fairly complete picture of the context. The interviews were organized as one workshop in each hamlet, where each workshop focused primarily on two or three out of the six themes. All elders approximately above the age of 60 and living in the hamlet were invited, and sometimes also a few from some adjacent hamlet. The oldest participants were born in the 1920's. Also secondary school students or, in one case, primary school students, were invited.
Most of the workshops were held in a private home of some resident in the respective hamlet, where the hostess served drinks of asua (a locally made brew made of cassava) to create a comfortable setting for the elders. A local assistant opened the discussion and directed it, but the elders were encouraged to talk freely, without much concern about strictly following the pre-elaborated question scheme. Also the students were encouraged to ask questions to the elders. Myself and an additional assistant took notes and I also made followup questions. Often several discussions took place simultaneously, and therefore the three of us always were seated spread out so that we together would catch everything that was said during the session. The following morning the three of us would meet in order to transcribe our notes on the computer. After having done three such workshops, the resulting transcribed material was codi- 
fied and restructured according to the time epochs and themes previously defined. The material was analyzed in order to identify what particular pieces of information were missing, and a corresponding list of specific questions was elaborated. During the fourth and fifth workshop, this list was used in addition to the original interview scheme.

Reconstructing the demographic history of the community was done based on various additional sources, including previously published regional estimates of pre-Columbian population density, historical source documents from the study area, population data published in El Oriente Dominicano, the news bulletin of the Dominican Mission in the town of Puyo, (1929: 8; 1929: 9; 1930: 17; 1937: 70-71; 1943: 118; 1947: 172), official censuses (INEC 1974, 1982, 1990, 2001), and retrospective mapping (cf. Sadomba 1996) at separate community workshops in each hamlet, where the local participants made maps indicating all households present in the years 1941, 1960, 1978, and 2001 (Fig. 2). Recent population numbers and trends were estimated based, in addition, on unofficial censuses made by Edeli et al. (1998) and Sirén (2004), as well as unpublished 2001 pre-census data of the National Ecuadorian Institute for Censuses (INEC), and inspection, for quality assessment purposes, of the filled-in cen- sus forms for of the 2001 official census. This latter revealed that the quality was very poor and very many residents omitted. This was probably because, different from the pre-census that was carried out by INEC staff, the census itself was carried out by local teachers with little training and little motivation for this additional work task imposed upon them. The utility of official census reports is limited also because they do not provide numbers for the population at the level of the Sarayaku community, but only for the parish center, which is just one of the five hamlets in the community, and for the entire parish, which includes also several neighboring communities. For further details on methodology, see Sirén (2004: 67-71).

The findings are presented in the following order. First, demography, then settlement pattern and agriculture, and, finally, hunting. The reason for using this order is that although quantitative and spatially explicit data on hunting in the past is virtually absent, one can make some deductions about it based on what is known about demography and spatial patterns of settlement. And although quantitative data is scarce also on past agriculture, one can draw conclusions about it using deduction based on known demographic changes.

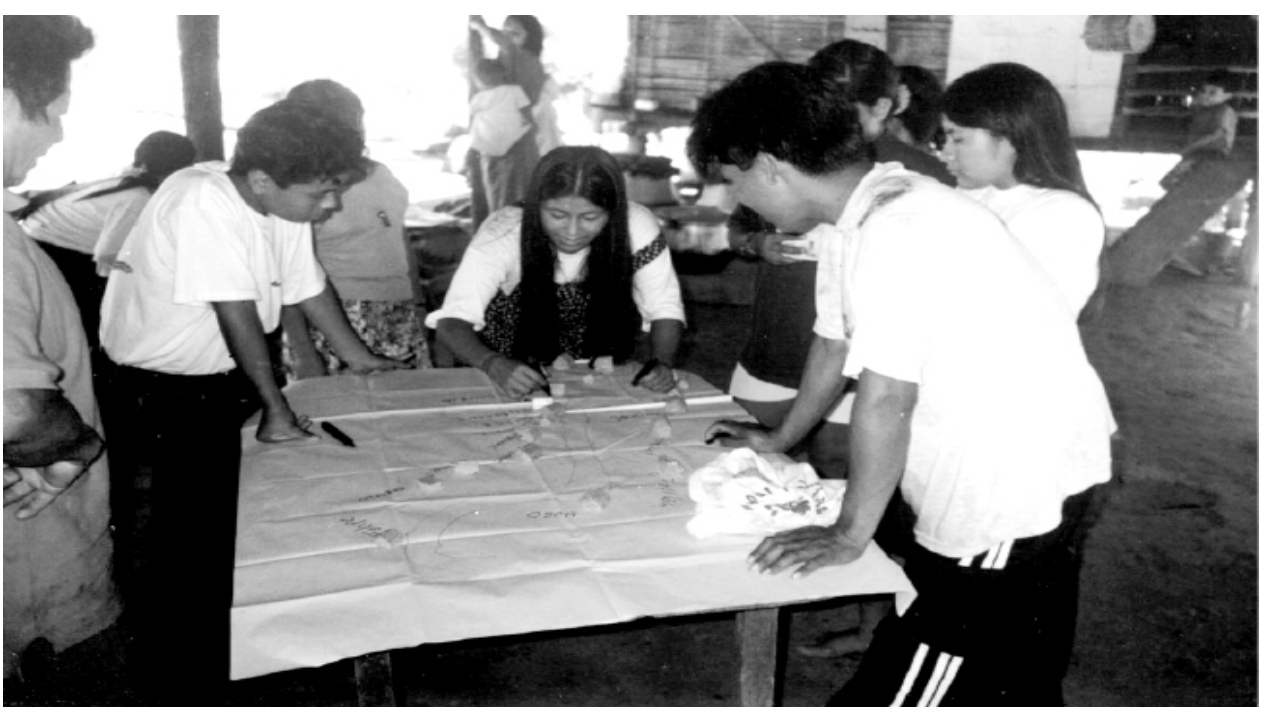

Fig. 2. Participatory mapping of demographic changes in the community. The youngest generation of participants at a workshop in the hamlet of Sarayakillu make a map of the present. Subsequently, participants representing progressively older generations made similar maps of the past. 


\section{Demography}

Population density in the Americas before 1492 can only be very crudely estimated, due to the scarcity of data. Newson (1996) estimated the pre-Columbian population density to $0,34-0,43$ persons $/ \mathrm{km}^{2}$ for a huge area including our study area and stretching from the base of the Andes in the west to the Marañon River in the south and the Putumayo River in the northeast. After the arrival of Europeans to the American continent in 1492, the population decreased, and is believed to have reached its nadir around 1760 (Taylor 1986). Some contemporary accounts from the study area seem to confirm that population density was indeed very low in the area in the mid- $18^{\text {th }}$ century. In 1737, finding footsteps some $40 \mathrm{~km}$ downriver from the site of the current Sarayaku village was a curiosity for a party of missionaries travelling up the Bobonaza (Tobar-Donoso 1960: 132). In 1769, the only survivor of a shipwrecked party on the lower Bobonaza, Mrs. Isabel Goudin, had to walk for nine days - apparently without finding any trails or other signs of human presence - until she met two Indians travelling on the river, who saved her life (Whittaker 2005).

An estimate, which appears to be trustworthy, of the population of Sarayaku was provided for the years $1888-1889$ by a missionary who travelled widely in the region and recorded the number of inhabitants of over 20 settlements or forest areas, in some of which he even distinguished between 'infidels' and 'Christians' (Magali 1978: 45). According to this source, the Sarayaku mission community had about 460 innhabitants, and in an addition, approximately 50 persons were living in the surrounding forests of the study area, such that this would altogether correspond to a population density of 0.39 inhabitants $/ \mathrm{km}^{2}$, suggesting that by then the population might have recovered to a level similar to that of pre-Columbian times. Available population data published by the Dominican Mission from 1928-1947 show highly fluctuating numbers, inconsistent with recorded numbers of baptisms and deaths, but suggest on the whole that the population had remained relatively stagnant since the late $19^{\text {th }}$ century, something which is supported also by a testimony of a missionary in Sarayaku in the 1930's:
"The marriages of the Indians are in general very fecund: ten or twelve children is the fruit of a union. Nevertheless, the population remains stagnant, because of the death of almost all of the children that succumb, victims of diseases and lack of food and disgraces of an abrupt nature." (Vargas 1931, translation by the author)

Since the 1940's, in any case, population growth has been rapid, although mitigated by high rates of emigration. A pre-census carried out in 2001 by governmental staff showed a population of 961 inhabitants in Sarayaku (INEC, unpublished data), a figure almost equal to a population count done by myself soon before. Taking into account that by then the territory effectively available to the Sarayaku people had shrinked somewhat due to the establishment of some new communities, the population density in 2001 can be estimated to 0.96 inhabitants $/ \mathrm{km}^{2}$, i.e. between two and three times higher than the regional pre-Columbian population density estimated by Newson (1996). The annual rate of population growth during the latter part of the $20^{\text {th }}$ century was estimated to $1.6 \%$ (Sirén 2004: 144).

\section{Settlement pattern and agriculture}

The demographic trends are also reflected in the need for food and thus, the land area under cultivation, although this is also affected by various other factors. Phytolithic records reveal that agriculture has been practiced in Ecuadorian Amazonia at least since 5300 B. P. Intensification of maize cultivation then seems to have occurred from about 2400 B.P. until 800 B.P., when maize disappears from the pollen record. Nevertheless, the amount of pollen from species typical of secondary forests indicates that cultivation of other crops probably continued to increase, although not resulting in massive deforestation as in other neotropical regions outside Amazonia (Piperno 1990). In the Sarayaku area, the earliest evidence - found so far - for human occupation dates from about 500 A.D., consisting of pieces of pottery found during archeological excavations at the Muritikucha- 1 exploratory oil well site. The site, situated on the crest of a ridge, has been repeatedly occupied up to the late 19th century (P. Netherly, pers. comm).

Elders in Sarayaku tell, with considerable detail, about a people they call the 'Tayak', which 
they consider the original people of the Sarayaku area. Historical source material from the region mentions a large number of different ethnic groups, but none with this name. Nevertheless, the Tayak mentioned by the Sarayaku elders do not seem to be a mythical people as suggested by Reeve (1988: 109), but a historical reality. The Sarayaku people recognize certain sites in the forest that they call tayak purun, the sites that used to be farmed by the Tayak people but that now are covered by high forest, and recognized based on the presence of pottery fragments or, much more seldom, stone axes on the forest floor, as well as sometimes a somewhat reddish color of the soil, a slightly different forest structure with absence of giant trees, or, sometimes, oral history alone. It is unclear, however, whether 'Tayak' originally was a generic term describing any nonmission Indians (similar to e.g. 'nomads' or 'savages'), or whether it referred to a particular ethnic group. For example, the Záparo people are in the local kichwa dialect referred to as 'Taway', and possibly these two similar terms may have the same origin and refer to the same people.

The Tayak are said to have used stone axes and knives made of bamboo, and to have lived only on the crests of the ridges, or hilltops, where they farmed mostly maize. These latter affirmations are supported also by other evidence. Archeological excavations in the Yasuní area in northeastern Ecuadorian Amazonia have shown that, in some interfluvial areas, Pre-Columbian human settlements were indeed found primarily on the ridges (Netherly 1997). Sediment cores taken from this area, however, seem to lack evidence of human landscape disturbance during the last 9,500 years (Weng et al. 2002). In sum, studies from relatively nearby sites suggest that, in preColumbian times, people practiced agriculture, but that the extent of deforestation was relatively small, and mostly limited to the crests of the ridges. An historical account from the lower Bobonaza in 1707 indicates that maize was the dominant crop in those times (Tobar-Donoso 1960: 239), similar to what the Sarayaku elders claim regarding the Tayak people. The travel account of Isabel Goudin in 1769, mentioned above, furthermore, indicates not only that the population density was low, but also that the few people who existed in the region did not have any settlements near the riverside (Whittaker 2005).

In any case, the Sarayaku people simultaneously consider the Tayak to be both their own an- cestors and a group of 'others' that to some extent was antagonistic to the ancestors who lived in the early mission community. Although this may appear paradoxical, it becomes much less to when considering that the settling in the mission community was a process spanning over several generations and involving the gradual adoption of the Kichwa language first as lingua franca and then as mother tongue and marker of a common ethnical identity. The last reference made to the Tayaks in oral history is that, in addition to that some gradually became settled in the mission community, the rest, who remained out in the forest, got virtually wiped out by a devastating smallpox epidemic. This probably occurred sometime in the mid- $19^{\text {th }}$ century, as the elders make no more references to the Tayak when talking about epochs later than this.

In addition to population density, also the kind of technology available can have profound implications for agricultural practices. In particular, metal tools most likely revolutionized the way agriculture was carried out. The adoption of metal tools in the Bobonaza region seems to have been a gradual process. In the late $18^{\text {th }}$ century, non-mission Indians acquired metal tools through trade with the Indians of the Canelos mission, 35 $\mathrm{km}$ upriver from Sarayaku, but metal tools continued to be in short supply, so that the non-mission Indians still had to rely partly on stone tools (Rumazo 1970: 124, 160). When the Sarayaku mission was founded in the early $19^{\text {th }}$ century, access to metal tools most probably improved significantly, as the Christianized Indians typically even became middlemen who traded industrial goods to the non-mission Indians, who in exchange provided blowguns and other traditional crafts that the Christianized Indians ceased to manufacture themselves (Spruce 1996: 435). Metal tools must have made it easier to make canoes, facilitating fishing as well as river transport. Probably they also made it much easier than before to have farm on the alluvial plains, which before may have been far too laborious to make it worthwhile. Clearing the forest on hilltops is still today easier than felling trees on alluvial plains, because the trees tend to have a larger crown on the downside slope, and the momentum of the fall often makes them come loose from the stump and fly several additional meters. Thus the crown lands outside the field area, and this saves much work of chopping up branches and twigs. When clearing for a field on a hilltop, the trees can be 
felled in this way to both sides of the ridge. Moreover, setting fire to big trees has previously been used as an auxiliary technique (Carneiro 1979) and this was probably easier on the crests where the forest tends to be drier. Also weeding is easier on the crests than on the alluvial plains, where weeds grow faster and often form a thick mat, which would be very hard to weed without metal knives.

Since the early $19^{\text {th }}$ century, thus, people increasingly came to settle and took up farming of the alluvial plains of the Bobonaza River. One may easily think that the change from dispersed settlement and farming on ridgetops to nucleated settlement and farming on alluvial plains was a direct effect of the establishment of the mission. However, some Sarayaku elders claim a few families already had settled along the river before the mission was established. Accounts from some nearby areas provide evidence for that the change of settlement from hilltops to riverside habitats at least in some cases did predate the establishment of mission communities. This was the case for the Záparos further downriver the Bobonaza in the mid-19 ${ }^{\text {th }}$ century (de Vernazza 1849) as well as for the Huaorani people further north in the 1950's (Cabodevilla 1999: 320-326).

Whereas the establishment of the mission community implied a change from disperse to nucleated settlement, this did not imply that the surrounding forests immediately got emptied of people. Many people continued to farm the ridges in the surrounding forest, including the Achuar people in the south and the Záparo to the north. Also, to avoid the domination by the priests, some people left the mission community and went to the forest to 'become záparos', as local elders put it. Ecuadorian geographer Villavicencio (1858) indicated that "only some [záparos] have small fields of maize, manioc and plantains, others live by hunting, fishing and wild fruits. They are almost nomads, following the ripening of the fruits." Similarly, oral tradition indicates that the Záparos in the Sarayaku area in the mid$19^{\text {th }}$ century relied heavily on forest fruits, game and fish, and that agriculture was limited to small fields of maize.

However, the people who settled in the mission community probably never completely abandoned the areas where they had come from which, after all, were not further away than that they could be reached by foot or canoe in a few days at the most. When passing the Rutunu River in 1857, the famous English botanist and explorer Richard Spruce noted that people from Sarayaku, Pakayaku and Canelos all along this river had purinas, i.e. secondary homes, where they went to wash gold (Spruce 1996: 125). Similarly, it has been described for the Canelos mission, $35 \mathrm{~km}$ upriver and established almost two centuries before the mission station in Sarayaku, that the people who settled in the mission community also continued having houses in their areas of origin, leading to the system of alternating residence in the village and in remote secondary homes, respectively, which is still in force (Guzmán-Gallegos 1997: 147). Local elders in Sarayaku tell that these remote purinas had an important role in the $19^{\text {th }}$ century, when the Sarayaku mission community at various occasions was abandoned due to smallpox epidemics, as the people dispersed out to their secondary homes in order to escape contagion.

Some of the more distant purinas (Fig. 1), however, have a somewhat more recent origin, according to the Sarayaku elders. During the rubber boom, which reached Sarayaku around 1890, almost all men as well as many women in Sarayaku worked collecting rubber. Different from many other areas, however, they never became subject to slavery or debt-bondage. They felled the rubber trees instead of tapping the rubber from standing trees, as was done in many other places. As the stands of rubber trees got depleted near the village, people had to go further away to collect rubber. Thus, they expanded their area of resource use and established new secondary homes in distant locations, which are still today used by their descendants. For a long time, people spent as much time in their purinas as in the mission community. The missionaries never had a permanent presence in Sarayaku. Still in the 1940's, the priest came and went in intervals of a few months, and most people lived dispersed in the secondary homes when the priest was not present (Un exCronista Misionero 1946; Sarayaku elders, pers. comm). In the 1940's the missionaries opened a school, which in 1943 had 18 pupils out of which 14 were native Indians (Sarayaku elders, pers. comm; Espinosa 1943a). The increasing importance in formal schooling would later have important repercussions for the spatial and temporal patterns of resource use in the area.

Up to the 1930's, land for agriculture was abundant, and almost all fields were made by clearing old-growth forest on good sites such as 
hilltops and alluvial plains. Also, land formed by recent river sedimentation was highly preferred sites for agriculture. Most fields were established by clearing primary forest. During World War II there was a boom in the farming of barbasco (Lonchocarpus nicou), which went to export for production of the insecticide rotenone, but very soon the demand ceased again (Sarayaku elders, pers. comm; Muñoz 1942). Beginning in the 1940's, old-growth forest near the village became scarce, so that people increasingly began to re-clear fallows instead. Towards the 1970's land scarcity around the village led to a shortening of the fallow times. The community decided that secondary forests belong to the people that first cleared it, and must not be cleared by others without the permission of the owner. This had long been the custom in one part of the village, downriver along the Bobonaza River, but now it became a rule in the whole community (Sarayaku elders, pers. comm; see also Sirén 2006, 2007).

In the 1970's, people increasingly engaged in harvesting fibers from the Aphandria natalia palms, typically felling trees found in the primary forest. The wild stands then started to get depleted, and this led to that many people began to plant these palms. The total area of plantations of $A$. natalia is, however small, the largest individual holding being only 0.6 ha. The planted palms began to become productive some 15 years after planting. However, as prices decreased towards the turn of the century, the interest in planting this palm has dropped and some of the plantations do nowadays not even get harvested.

In the 1980's, participation in formal schooling became basically universal, forcing most people to live in the permanent settlement during all year except school vacations, i.e. each year one short vacation of one month, and one longer of three months. Old-growth forest was becoming scarce in the vicinity of human settlements, and the proportion of fields made by clearing old-growth forest had decreased to around $30 \%$ of the total cleared area per annum (Sirén 2007). In 1984, about half of the households in Sarayaku cleared forest and sowed pasture, funded by loans from the government channeled through the Fund for Development of Marginal Rural Areas (FODERUMA). However, cattle rising did not turn out to be very profitable, and by 1998, most of the pastures had returned to fallow.

In the late 1990's the duration of school vacations decreased to just one month twice a year.
Thus, people now spend less time in the secondary homes than they used to do. In the 1990's, lack of good farmland in the vicinity of the settlements forced people to start to clear even steep slopes and stony soils, which previously were considered unapt for agriculture. By the turn of the century, about 18 hectares of old-growth forest was cleared annually, corresponding to a rate of expansion of the area of fields and fallows of $0.4 \%$ per year, considerably lower than the annual rate of population growth of $1.6 \%$, and corresponding to a deforestation rate of only $0.015 \%$ per year (Sirén 2004: Ch. 8; Sirén 2007).

In sum, agriculture has always been primarily for subsistence. Cultivation of crops for commercialization has occurred on a small scale, often limited in time to short-lived booms, and has not affected the forest cover very much. The location of settlement and cultivated land has undergone considerable changes (Fig. 3). First, agriculture took place scattered on the hilltops, then cultivation started also on the alluvial plains, and settlement and agriculture became more concentrated around the mission site, although people also lived in their distant secondary homes part of the year. In recent decades, an increasingly nucleated settlement pattern, population growth, and increased sedentarism due to universalized participation in formal schooling have led to land scarcity and quite intensive land use in a limited area around the village. Since some century ago, on the other hand, forests on remote ridges have recovered or continue recovering from the impacts of previous repeated clearing during several hundred or perhaps thousands of years.

In contrast to the dominating pattern up to the $19^{\text {th }}$ century, human settlement and agriculture are today quite concentrated in space, most agriculture taking place within a few kilometers from the five permanent hamlets (Fig. 4a). The current impact of agriculture on the forest cover in this area is probably greater than ever before in any part of the study area. Nevertheless, even here there are places where people do not clear the forest, particularly on steep slopes and in deep gorges (Fig. $4 b)$. The largest of these pockets of apparently untouched forest within the intensively used zone is about 500 meters wide, and located in an area of heavily intersected terrain with deep gorges alternating with knife-edge ridges (Fig. 4c, 4d). Such habitats have probably never ever been cleared, but, as discussed in the next section, they have been subject to the impacts of hunting. 

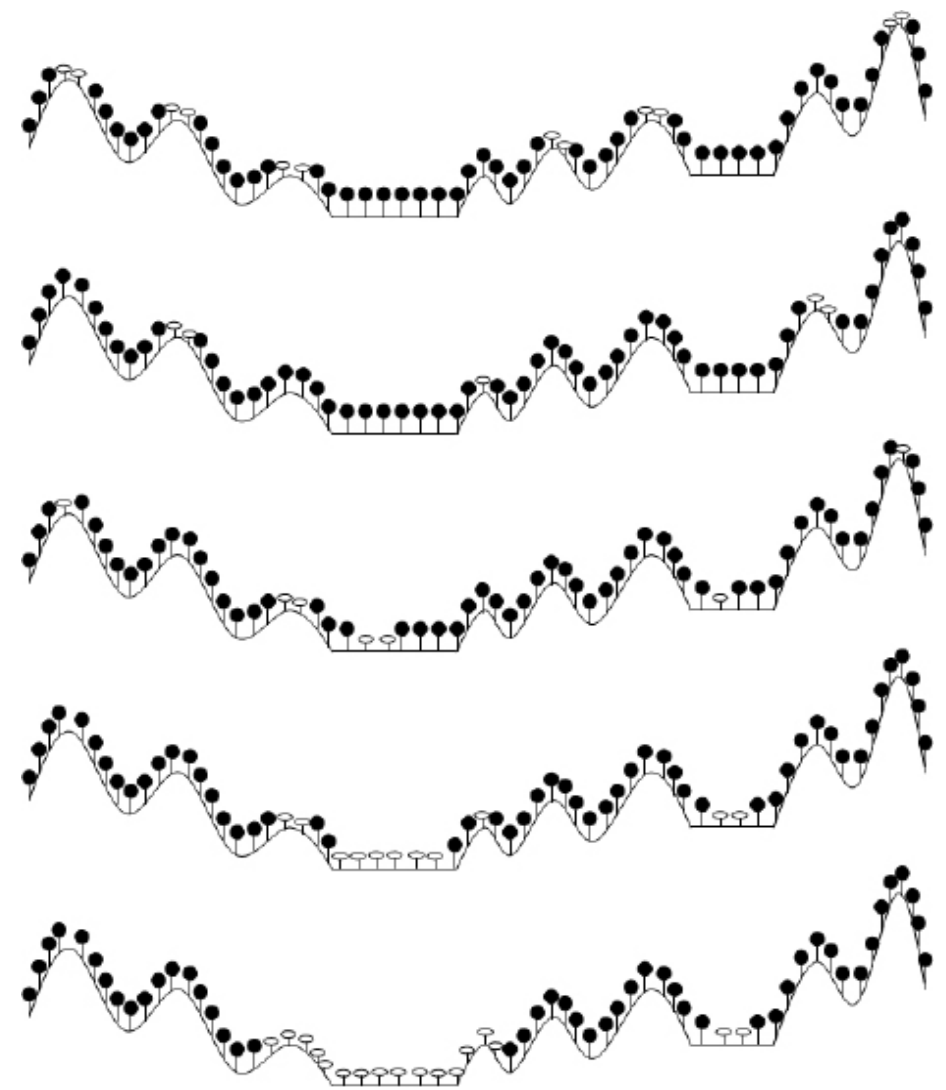

Fig. 3. Schematic representation of the changes over time in the spatial pattern of agricultural land use, in a northsouth cross-section of the Sarayaku territory. The tall black "trees" represent old-growth forest, while the small white "trees" represent cultivated areas and fallows. The figure is not to scale, and the width of the plains is exaggerated.

\section{Hunting}

Data on past hunting is very scarce, but some conclusions can be drawn by deduction, based on what is known about changes in population density and settlement pattern. Thus, overall hunting pressure must have decreased sharply as the population density decreased from the $16^{\text {th }}$ to the late $18^{\text {th }}$ century, and then hunting must also have increased when human the population started to increased again. On the other hand, the spatial distribution of hunting is also likely to have changed. Up to the early $19^{\text {th }}$ century, hunting effort must have been rather evenly distributed in space, but as people increasingly settled around the mission during the $19^{\text {th }}$ century, hunting effort must have become more concentrated in space, and even more so towards the latter part of the $20^{\text {th }}$ century when participation in formal schooling became universal. The marked spatial gradients in hunting effort and abundance of game animals observed today (Sirén et al. 2004) are thus probably a relatively recent phenomenon.

In addition, also changes in hunting technology can potentially have large impacts on what species are targeted by hunters. Sarayaku elders claim that the Tayak used bow and arrow as well as spears to hunt, but they disagree among themselves upon whether the Tayak also used blowguns or whether these were a later introduction. In the literature, Stirling (1938) and Metraux (1949), mention that the nearby Jívaro people at the time of first contact used bow and arrow, but Metraux (1949) also mentions that the Záparo, on the other hand, used blowguns but not bow and arrow. As high-quality dart poison was acquired through long-distance trade (Cipoletti 1988), disruptions and (re-)establishment of trade routes may have been one 


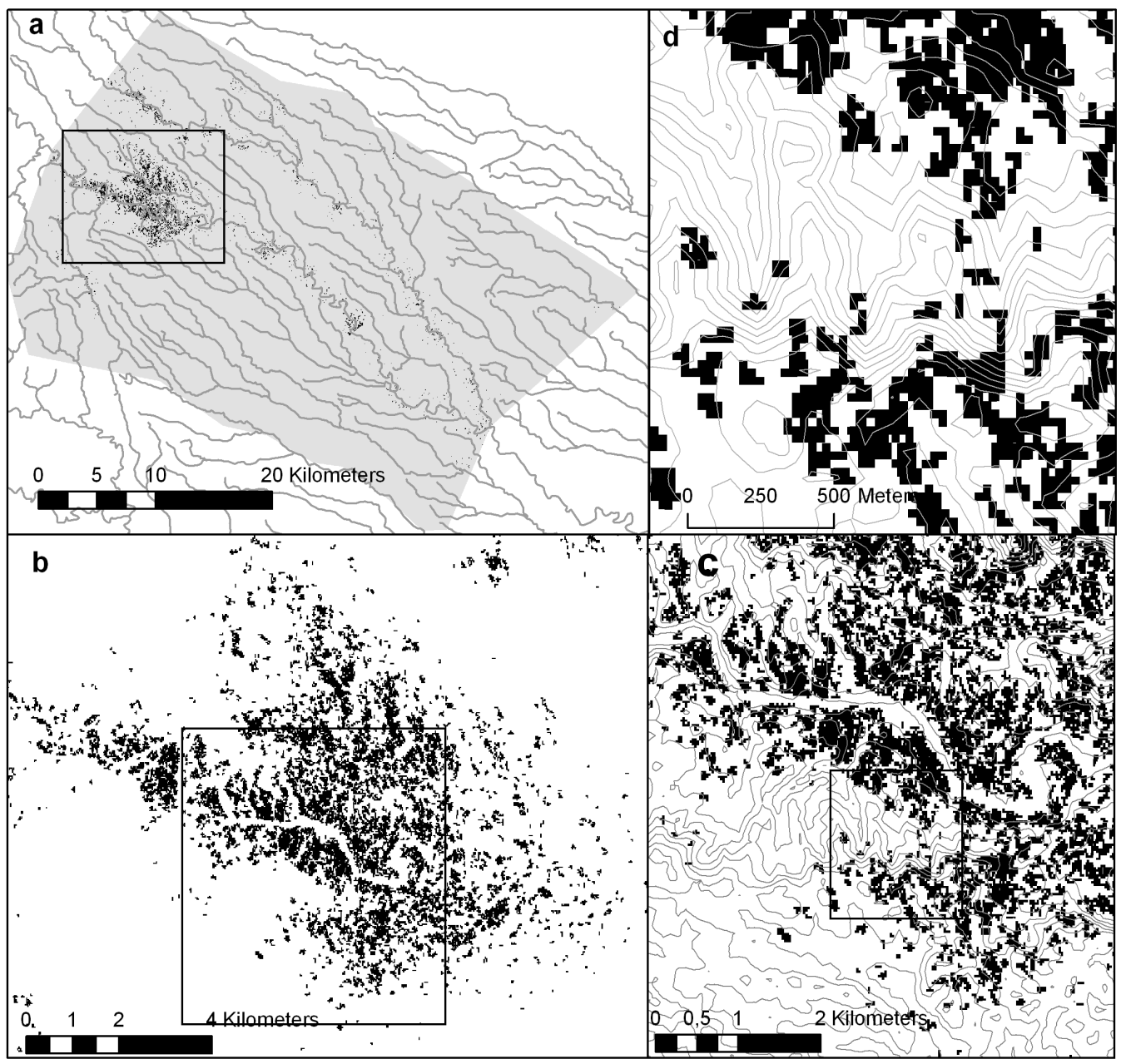

Figure 4. Current location of agricultural fields and fallows, based on remote sensing analysis. Black color indicates areas identified as fields or fallows younger than 20 years, on Landsat TM and ETM+ images from 1987 and 2001. Extent rectangles on each map indicates the location of the subsequent map. A: Location of agricultural fields and fallows in the study area. Light gray color indicates the extent of the study area. Dark gray lines represent rivers. B: The intensively used zone around the hamlets. C Close-up with 20-meter contour lines. D: Close-up with 10-meter contour lines. Note 500-meter wide strip of forest unaffected by clearing and farming. For details about the image interpretation procedure, see Sirén (2004, 2007) and Sirén \& Brondizio (2009).

cause behind changes in hunting technology. The blowgun is more apt for hunting canopyliving animals, whereas the bow and arrow is more apt for hunting ground-living animals (Sarayaku elders, pers. comm; see also e.g. Chagnon 1997: 51) and these shifts of hunting technology may therefore have caused corresponding changes in the animal community structure.
In the 1940's, the blowgun was still the dominating hunting weapon (Un ex-Cronista misionero 1946) but already in the 1950's, they were gradually being replaced by muzzle-loaded shotguns (Sarayaku elders, pers. comm; Maya 1959), Ammunition was however expensive, so still in the 1960's people used to carry both a blowgun and a shotgun when hunting, and they loaded just 3-5 shots, which they then carefully re- 
trieved from the carcass in order to reuse them. Later, cartridge shotguns gradually replaced the muzzle-loaded ones. By the turn of the $20^{\text {th }}$ century, both types of guns were about equally common, whereas blowguns were by then used just for playing or as a training tool for young boys.

Another important change of hunting technology was the introduction of dogs, as the use of dogs greatly facilitates hunting of several groundliving species, such as pacas (Seniculus paca), collared peccaries (Pecari tajacu) and tapirs (Tapirus terrestris). Hunting dogs have been used in the area for such a long time that local elders consider them to have existed "always". It has also been documented that they were common in the mission communities in the region as early as in the mid-19 $9^{\text {th }}$ century (Spruce 1996). However, hunting dogs in fact seem to have been absent in much of Amazonia until the last few centuries. The Huaorani people, living a couple of hundred kilometers to the north, adopted hunting dogs just towards the latter part of the $20^{\text {th }}$ century, after contact and settlement in permanent villages (Yost \& Kelley 1983). Apparently, the use of hunting dogs among Amazonian indigenous peoples becomes common only when there is enough contact with urban centres such that new dogs can continuously be brought in order to replace those that succumb due to disease, parasites, snake bites, or other calamities (cf. Koster 2009). In the 1960's, Sarayaku hunters began to hunt with flashlights. The flashlights facilitated hunting of pacas, armadillos and caimans, and the shotguns facilitated hunting of all species, although particularly ground-living ones.

Whereas population density is one important determinant of hunting intensity, this also depends on any commercial demand for wildlife products, in addition to the local demand for subsistence needs. From the 1940's up to the 1960's, Ecuadorian merchants visited regularly Sarayaku in order to buy furs from spotted cats, otters (Lontra longicaudis), giant otters (Pteronura brasiliensis) and collared peccaries (P. tajacu), as well as the feathers of toucans (Ramphastos spp.), and live monkeys (Sarayaku elders pers. comm, Blomberg 1964: 19). Contrary to what has been documented for many other places, however, local elders claim that this trade did not affect the abundance of the species in question in the Sarayaku area.

Towards the turn of the $20^{\text {th }}$ century, a resurgence of ethnic pride among indigenous commu- nities near the towns of Puyo and Tena, caused an increased demand for wild game meat which could not be satisfied locally because game habitats had long since been converted to farmlands and pasture. Thus, a few times Sarayaku hunters were paid to hunt to provide wild meat for such events, but the community soon decided to prohibit such 'export'.

The demand for wildlife products also depends on the availability of other sources of food of similar nutritional value that could act as substitutes for wild meat. In this sense, the reliance on fish probably has increased over time, and it was estimated in 2001 that the amount of fish caught in the community was about 2.5 times larger than the amount of wild game hunted. Other sources of food of animal origin were of very minor importance all the way up to the end of the $20^{\text {th }}$ century (Sirén \& Machoa 2008).

It is to expect that the rapid demographic increase during the latter part of the $20^{\text {th }}$ century would lead to a decline of, at least, the most vulnerable game species, and the testimonies of the Sarayaku people confirm that this has happened. Local elders tell that in the 1930's, for example, spider monkeys and wooly monkeys were still common at a distance of just some four kilometers from the village. In the 1960's people typically travelled just $6-15 \mathrm{~km}$ downriver in order to hunt wooly monkeys for the annual community festival, whereas today these areas are extirpated of this species. The forests around the Wiuyaku creek (Fig. 1) are located in one of the remotest corners of the Sarayaku lands, at a distance from the main settlement of over $40 \mathrm{~km}$ by canoe followed by some $10 \mathrm{~km}$ by foot. Up to the mid 1990's there was no trail leading to this area and it had not been visited by humans for several decades. A few intrepid hunters, however, went there in the early 1990's and were followed by others, such that a few years later there was already a trail leading to the area. Towards the turn of the $20^{\text {th }}$ century, festival hunters each year travelled to this area to hunt wooly monkeys, which by now had become very rare everywhere else. In addition, the area also became subject to hunting by hunters from the recently formed Masaramu community, such that this safe haven for wooly monkeys is now disappearing. For spider monkeys the situation is even worse as family groups have not been observed for decades, and only occasionally single individuals are observed. 
The people have over time come to hunt a wider variety of species than before, not only because of improved hunting technology that have facilitated hunting of species that before were difficult or impossible to hunt, but also as an adaptation to increasing scarcity of the most preferred game species. Sarayaku elders tell that their forefathers during the 19th century "...ate only good meat. In those days they did not eat capuchin mokey (Cebus albifrons), saki monkey (Pithecia Monachus) or deer (Mazama spp.)." Today these species, especially deer, are quite commonly hunted and eaten, although still not held in very high esteem. The white-lipped peccary (Tayassu pecari) disappeared completely in 1992 perhaps due to disease outbreak (cf. Fragoso 1997), but reappeared in 2001, and is now again abundant (Sirén 2012).

In 2003 the community set aside a wildlife reserve where all hunting became prohibited, and another reserve was set aside in the same way in 2005 . These reserves are patrolled by forest guards appointed by the community and paid with funds provided from Germany. These reserves cover about $40 \mathrm{~km}^{2}$ each. The intensity of hunting has decreased in the reserves, as evidenced by the disappearance of the hunting trails that previously crisscrossed the areas. Occasional incursions by hunters unwilling to obey to community decisions nevertheless still occur.

In sum, hunting has been taking place basically everywhere. However, its overall intensity has varied with human demographic changes, decreasing from the $16^{\text {th }}$ or $17^{\text {th }}$ century up to the late $19^{\text {th }}$ century, then to increase again. Its spatial pattern has also changed, being increasingly concentrated in space since the mid $19^{\text {th }}$ century. In the immediate vicinity of the Sarayaku community, hunting intensity has thus increased continuously ever since the early $19^{\text {th }}$ century. In remoter areas, however, hunting intensity may have decreased as settlement became more sedentarized and nucleated. During the last couple of decades, however, hunting intensity in these remote areas seems to have increased again, as human populations have grown, new villages have been founded, and as depletion of game around settlements forces hunters to travel ever further away in order to find prey. Ultimately, the establishment of wildlife reserves has decreased the hunting pressure, although only in two limited areas.

\section{Discussion and conclusions}

Some $96 \%$ of the Sarayaku area consists of oldgrowth forest (Sirén 2007), but some of it has, at some point in history, been cleared for agriculture. Until recently, however, such forest clearing was limited to the crests of the ridges. Only since early $19^{\text {th }}$ century have people cleared forests on alluvial plains of the major rivers, and only since a few decades back on steep slopes. Still they do not clear the forest in deep gorges, and rarely on alluvial plains of smaller forest creeks. Thus, much of the study area has probably never been deforested. Hunting, on the other hand, has affected the study area in its totality. Whether extinction of megafauna caused by early humans has changed forest structure, as suggested by Schüle (1992) cannot be confirmed, but for sure recent hunting has decimated populations of primates, as well as of large birds and ungulates (Sirén et al. 2004), and this without doubt causes cascade effects that affect the whole ecosystem, although much less drastically than does outright forest clearing. The intensity of hunting has, however, also been changing, and so has also its spatial pattern. In spite of growing population and improvements in hunting technology, the changes in settlement pattern during the $19^{\text {th }}$ and $20^{\text {th }}$ century also created almost unhunted refuges in those areas that became remote from nucleated settlements. These refuge areas have recently come under threat to disappear as new communities are founded and hunters reach further and further into the forest. The changes over time in the intensity of human resource use and corresponding ecological impacts have varied in space depending on, in particular, topographical location and distance from the village (Table 2).

The historical developments described in this paper are not all unique to the Sarayaku area. On the contrary, demographic decline followed by recovery, and dispersed settlement gradually being replaced by nucleated settlements around Christian missions, are processes that have affected vast expanses of the non-flooded upland areas of western Amazonia (e.g. Taylor 1986). Thus, much of the conclusions reached here may be generalizable for large areas outside the study area itself, although such extrapolation always must be done with great care, considering possible differences in human history as well as in the natural environment. 
Table 2. A stylized summary of how the historical changes in impacts of forest clearing and hunting have varied in space, depending on topographical location and distance from the village. Note that the word "never" here is used as an abbreviated form for "most likely never during the last five centuries and, according to currently available data, perhaps not before that either".

\begin{tabular}{|c|c|c|c|c|}
\hline & & Plains & Slopes & Hilltops \\
\hline Nearby & Forest clearing & $\begin{array}{c}\text { Clearing began } \\
\text { around year } 1800 . \\
\text { Almost all land has } \\
\text { by now been cleared } \\
\text { at least once. }\end{array}$ & $\begin{array}{c}\text { Forest has been } \\
\text { increasingly cleared } \\
\text { since various } \\
\text { decades back. Some } \\
\text { forest remains that } \\
\text { has never been } \\
\text { cleared }\end{array}$ & $\begin{array}{c}\text { Clearing began } \\
\text { around year } 1800 \text { or } \\
\text { earlier. Almost all } \\
\text { land has by now } \\
\text { been cleared at least } \\
\text { once. }\end{array}$ \\
\hline
\end{tabular}

Hunting Hunting intensity decreased from $16^{\text {th }}$ to $18^{\text {th }}$ century. It has then drastically increased since the mid- $19^{\text {th }}$ century

\begin{tabular}{|c|c|c|c|}
\hline Remote & Forest clearing & Forest has never been cleared & $\begin{array}{l}\text { After centuries or } \\
\text { millennia of repeated } \\
\text { clearing the forest is } \\
\text { now recovering } \\
\text { since the mid } 20 \text {-th } \\
\text { century or, in many } \\
\text { places, much earlier }\end{array}$ \\
\hline & Hunting & \multicolumn{2}{|c|}{$\begin{array}{l}\text { Hunting intensity decreased from } 16^{\text {th }} \text { to } 18^{\text {th }} \text { century, then increased } \\
\text { again. It may have decreased during part of the } 19 \text { th and } 20^{\text {th }} \text { century } \\
\text { but during the last few decades it has probably increased again. }\end{array}$} \\
\hline
\end{tabular}

Explaining the reasons behind the observed changes in settlement pattern and resource use is challenging, and attempting to do so inevitably gives rise to several new questions. One important question is why the people used to live only on the ridges and why they then moved down to the alluvial plains. Defense from tribal enemies (as well as Spaniards) was probably one reason for choosing to live on the ridges. The need for defense, however, continued also after people settled around the missions, as the missions sometimes were attacked by antagonistic Indians as well as slave raiders. Obviously bearing this danger in account, the missions were preferably established on high bluffs near the Bobonaza River, surrounded as much as possible by water or deep gorges, and such attacks were often successfully fended off, indicating that strategic sites for defense were available also near the large rivers (Casewitz et al. 1988: 136; Reeve 1988: 64; Spruce 1996: 439; Steward \& Metraux 1948: 632). As there are also cases where people settled at the river side before the establishment of missions, defense reasons or religion are hardly enough to explain this shift. Technological changes such as improved access to metal tools may have played a role.

Again, one must note, however, that on the alluvial plains of larger rivers such as the Napo, the lack of metal tools did not hinder the development of agriculture practiced by densely populated complex societies (Evans \& Meggers 1968, 1973), and this highlights the importance of recognizing that the subsistence strategies may have varied from place to place due to different environmental preconditions.

The forest of the Sarayaku area is not completely 'pristine', but nor is it 'anthropogenic'. It is a mosaic of forest subject to impacts of varying intensity and character, which during different epochs in the past have followed very distinct spatial patterns. This is probably true also for many other parts of Amazonia. Only detailed ecological field study can reveal what legacies this has left in terms of corresponding spatial patterns in the structure and species composition of the forest. 


\section{ACKNOWLEDGEMENTS}

I feel deep gratitude to the elders who kindly shared their knowledge about the history of Sarayaku; Delia Aranda, Ingracia Aranda, Virginia Dahua, Lucia Gayas, Alicia Gualinga, Ambrosia Gualinga, Basilio Gualinga, Camila Gualinga, Delfina Gualinga, Eloisa Gualinga, Imelda Gualinga, Sabino Gualinga, Sarita Gualinga, Delacio Guerra, Amelia Imunda, Atanacio Imunda, Salvador Imunda, Alfredo Malaver, Gonzalo Malaver, Rafael Malaver, Antonio Manya, Erlinda Manya, Corina Montalvo, Aurora Santi, Luzmila Santi and Rito Santi, and in particular to those of them who have, since then, already passed away; Hugo Aranda, Isilinda Cisneros, Hilda Gualinga, Ricardo Gualinga, Serafina Illanes, Felipe Machoa, Francisco Machoa, Jacinto Machoa, Luperta Machoa, Marcia Machoa, Belisario Malaver, Ignasia Malaver, Plutarco Malaver, Basilio Santi, Belisario Santi, and Miguel Santi. Thanks also to the staff at the Vicariato Apostólico de Puyo for providing access to their library, and likewise to Father Antonio Cabrejas of the Dominican Convent in Quito. Thanks to Patricia Netherly for sharing unpublished information from archeological excavations at the Moretecocha-1 well site, and to Emilio Moran for inspiring discussions. Thanks to José Machoa and Reinaldo Guerra for assistance with field work, and to Jan Bengtsson, Eduardo Brondizio, David Gibbon, Tekeste Negash, Noemi Gualinga, Anders Öckerman, and Matti Salo for reviewing early versions of the manuscript, as well as to two anonymous referees who provided valuable suggestion for improvements. Field work was funded by the Swedish International Development Authority (SIDA) and the final writing was funded by a grant from the Kone Foundation to Prof. Risto Kalliola under its program for research on biodiversity.

\section{REFERENCES}

Balée W 1989. The culture of Amazonian forests. Advances in Economic Botany 7, 1-21.

Balée WC 1992. Indigenous history and Amazonian biodiversity. In Steen HK \& Tucker RP (Eds). Changing tropical forests: Historical perspectives on today's challenges in central \& south america, 233-251. Forest History Society / IUFRO Forest History Group.

Barlow J, Gardner TA, Lees AC, Parry LP \& Peres CA 2012. How pristine are tropical forests? An ecological perspective on the pre-Columbian human footprint in Amazonia and implications for contemporary conservation. Biological Conservation 151: 1, 45-49. http://dx.doi.org/10.1016/j.biocon.2011.10.013.

Blomberg R 1964. Människor i djungeln. Almqvist \& Wiksell, Stockholm.

Bush MB \& Colinvaux PA 1994. Tropical forest disturbance: Paleoecological records from Darien, Pan- ama. Ecology 75: 6, 1761-1768. http://dx.doi. org/10.2307/1939635.

Bush MB \& Silman MR 2007. Amazonian exploitation revisited: ecological assymetry and the policy pendulum. Paleoecology 5: 9, 457-465. http:// dx.doi.org/10.2307/1939635.

Cabodevilla MA 1999. Los Huaorani en la historia de los pueblos del Oriente. Cicame, Coca.

Carneiro RL 1979. Tree felling with the stone ax: An experiment carried out among the Yanomamö indians of southern Venezuela. In Kramer C (Ed). Ethnoarchaeology: Implications of ethnography for archaeology, 21-58. Columbia University Press, New York.

Casewitz R 1988. Al este de los Andes : relaciones entre las sociedades amazónicas y andinas entre los siglos XV y XVII. Abya-Yala, Quito.

Cipoletti MS 1988. El tráfico de curare en la cuenca amazónica (Siglos XVIII y XIX). Anthropos 83, 527-540.

Chagnon NA 1997. Yanomamö. Harcourt Brace College Publishers, London.

Cleary D 2001. Towards an Environmental History of the Amazon: From Prehistory to the Nineteenth Century. Latin American Research Review 36: 2, 64-96.

Denevan WM 1992. The Pristine Myth: The Landscape of the Americas in 1492. Annals of the Association of American Geographers 82, 369-385. http://dx.doi.org/10.1111/j.1467-8306.1992. tb01965.x.

Denevan WM 1996. A bluff model of riverine settlement in prehistoric Amazonia. Annals of the Association of American Geographers 86: 4, 654-681. http://dx.doi.org/10.1111/j.1467-8306.1996.tb01771.x. Denevan WM 2011. The "Pristine Myth" revisited. Geographical Review 101: 4, 576-591. http:// dx.doi.org/10.1111/j.1931-0846.2011.00118.x.

Edeli D, Gualinga B, Malaver M, Viteri F, Viteri R \& Viteri S 1998. Censo y estudio comunitario de Sarayacu. Colegio Técnico Agropecuario Sarayacu, Sarayacu.

Espinosa BM 1943a. Cronica Misional. El Oriente Dominicano 118, 27.

Espinosa B 1943b. San Antonio de Sarayacu. El Oriente Dominicano 122, 145-148.

Evans C \& Meggers BJ 1968. Archeological investigations on the Río Napo, eastern Ecuador. Smithsonian Institution Press, Washington.

Evans C \& Meggers BJ 1973. La reconstrucción de la prehistoria Amazónica. Amazonia Peruana IV: 7.

Foster DR \& Turner II BL 2004. The long view: Human-environment relationships in the region 1000 BC - AD 1900. In Turner II BL, Geoghega J \& Foster DR (Eds). Integrated land-change science and tropical deforestation in the southern Yucatán, 23-38. Final frontiers, Oxford.

Fragoso JMV 1997. Desapariciones locales del baquiro labiado (Tayassu pecari) en la Amazonía: Migración, sobre-cosecha, o epidemia? In Fang 
TG, Bodmer RE, Aquino R \& Valqui M (Eds). Manejo de Fauna Silvestre en la Amazonía, 309-312. Instituto de Ecología, La Paz.

Gómez-Pompa G \& Kaus A 1992. Taming the wilderness myth. Bioscience 42: 4, 271-279. http://dx. doi.org/10.2307/1311675.

Guzmán-Gallegos MA 1997. Para que la yuca beba nuestra sangre. Abya-Yala, Quto.

INEC 1974. III Censo nacional de población y II de vivienda. Instituto Nacional de Estadísticas y Censos de Ecuador, Quito.

INEC 1982. IV Censo nacional de población y III de vivienda. Instituto Nacional de Estadísticas y Censos de Ecuador, Quito.

INEC 1990. V Censo nacional de población y IV de vivienda. Instituto Nacional de Estadísticas y Censos de Ecuador, Quito.

INEC 2001. VI Censo nacional de población y V de vivienda. Instituto Nacional de Estadísticas y Censos de Ecuador, Quito.

Jerves P 1930. Las misiones Dominicanas en el Oriente Ecuatoriano (Continucación). El Oriente Dominicano 13, 51-57.

Koster J 2009. Hunting dogs in the lowland Neotropics. Journal of Anthropological Research 65: 4, 575-610.

Levis C, de Souza PF, Schietti J, Emilio T, da Veiga Pinto JLP, Clement CR \& Costa FR 2012. Historical Human Footprint on Modern Tree Species Composition in the Purus-Madeira Interfluve, Central Amazonia. PloS one 7: 11, e48559. http:// dx.doi.org/10.1371/journal.pone.0048559.

Magali JM 1978. Colección de cartas sobre las misiones Dominicanas del Oriente. Mundo Shuar, Quito.

Maya V 1959. Relación del recorrido Misional efectuado por el R. Valentín Maya, O. P., por los pueblos de la M. Dominicana. El Oriente Dominicano 311, 94.

Mayle FE, Langstroth RP, Fisher RA \& Meir P 2007. Long-term forest-savannah dynamics in the Bolivian Amazon: implications for conservation. Philosophical transactions of the Royal Society of London Biological Sciences 362: 1478, 291-307. http://dx.doi.org/10.1098/rstb.2006.1987.

McMichael CH, Piperno DR, Bush MD, Silman MR, Zimmerman AR, Raczka MR \& Lobato LC 2012. Sparse Pre-Columbian Human Habitation in Western Amazonia. Science 336: 6087, 1429-1431.

http://dx.doi.org/10.1126/science.1219982.

McMichael CH, Bush MB, Piperno DR, Silman MR, Zimmerman AR \& Anderson C 2012. Spatial and temporal scales of pre-Columbian disturbance associated with western Amazonian lakes. The Holocene 22: 2, 131-141.

http://dx.doi.org/10.1177/0959683611414932.

Metraux JH 1949. Weapons. In Steward JH (Ed). Handbook of South American Indians, 229-263. Vol. 5. Smithsonian Institution, Bureau of American Ethnology, Washington, DC.
Milner-Gulland EJ 2008. New perspectives on harvesting as one driver of ecosystem dynamics. Journal of Applied Ecology 45, 1-3. http://dx.doi. org/10.1111/j.1365-2664.2007.01455.x.

Muñoz JE 1942. La planta denominada barbasco. Oriente Dominicano 109, 98.

Muratorio B 1991. The life and times of grandfather alonso. Culture and history in the upper Amazon. New Brunswicks Rutgers University Press.

Newson LA 1996. The population of the Amazon basin in 1492: a view from the Ecuadorian headwaters. Transactions of the Institute of British Geographers 21: 1, 5-26.

http://dx.doi.org/10.2307/622921.

Netherly P 1997. Loma y ribera: Patrones de asentamiento prehistóricos en la Amazonía ecuatoriana. Fronteras de investigación 1, 33-54.

Peres CA \& Lake IR 2003. Extent of nontimber resource extraction in tropical forests: accessibility to game vertebrates by hunters in the Amazon basin. Conservation Biology 17: 2, 521-535. http://dx.doi.org/10.1046/j.1523-1739.2003.01413.x.

Pierre F 1983. Viaje de exploración al Oriente Ecuatoriano. Abya-Yala, Quito.

Piperno DR 1990. Aboriginal agriculture and land usage in the Amazon Basin, Ecuador. Journal of Archaeological Science 17, 665-677. http://dx. doi.org/10.1016/0305-4403(90)90048-A.

Pärssinen M, Schaan D \& Ranzi A. 2009. Pre-Columbian geometric earthworks in the upper Purúes: a complex society in western Amazonia. Antiquity 83, 1084-1095.

Redford K \& Feinsinger P 2001. The half empty forest: sustainable use and the ecology of interactions. In Reynolds J, Mace G, Redford K \& Robinson J (Eds). Conservation of Exploited Populations, 370-400. Cambridge University Press, Cambridge.

Reeve ME 1988. Los Quichuas del Curaray: El proceso de formación de la identidad. Abya-Yala, Quito.

Roosevelt AC 1999. The development of prehistoric complex societies: Amazonia, a tropical forest. Archeological Papers of the American Anthropological Association 9: 1, 13-33. http://dx.doi. org/10.1525/ap3a.1999.9.1.13.

Rumazo J (Ed) 1970. Documentos para la historia de la Audienca de Quito. Tomo VIII. Afrosidio Aguado, Madrid.

Räsänen ME, Salo JS, Jungner H \& Romero Pittman L 1990. Evolution of the Western Amazon lowland relief: impact of Andean foreland dynamics. Terra Nova 2, 320-332.

http://dx.doi.org/10.1111/j.1365-3121.1990. tb00084.x.

Sadomba WZ 1996. Retrospective community mapping: a tool for community education. PLA NOTES, 9-13.

Salo M, Sirén A \& Kalliola R 2014. Diagnosing wild species harvest: Resource use and conservation in the tropics. Academic Press, London. 
Sawyer S 1997. The 1992 Indian Mobilization in Lowland Ecuador. Latin American Perspectives 24: 3, 65-82. http://dx.doi.org/10.1177/0094582X9702400305.

Schüle W 1992a. Anthropogenic Trigger Effects on Pleistocene Climate? Global Ecology and Biogeography Letters 2, 33-36. http://dx.doi.org/10.2307/2997668.

Schüle W 1992b.Vegetation, megaherbivores, man and climate in the quaternary and the genesis of closed forests. In Goldhammer JG (Ed). Tropical forests in transition: Ecology of natural and anthropogenic disturbances and processes, 45-76. Birkhäuser Verlag, Basel.

Sirén A 2004. Changing interactions between humans and nature in Sarayaku, Ecuadorian Amazon. Acta Universitatis Agriculturae Sueciae: Agraria 447.

Sirén AH 2006. Natural resources in indigenous peoples' land in Amazonia: A tragedy of the commons? The International Journal of Sustainable Development and World Ecology 13, 363-374. http://dx.doi.org/10.1080/13504500609469686.

Sirén A 2007. Population growth and land-use intensification in a subsistence-based indigenous community in the Amazon. Human Ecology 35, 669-680. http://dx.doi.org/10.1007/s10745-0069089-y.

Sirén AH 2012. Festival hunting by the kichwa people in the Ecuadorean Amazon. Journal of Ethnobiology 32: 1, 30-50. http://dx.doi.org/10.2993/02780771-32.1.30.

Sirén AH \& Brondizio ES 2009. Detecting subtle land use change in tropical forests. Applied Geography 29: 2, 201-211. http://dx.doi.org/10.1016/j.apgeog.2008.08.006.

Sirén A, Hambäck P \& Machoa J 2004. Including spatial heterogeneity and animal dispersal when evaluating hunting: A model analysis and an empirical assessment in an Amazonian community. Conservation Biology 18: 5, 1315-1329. http:// dx.doi.org/10.1111/j.1523-1739.2004.00024.x.

Sirén AH \& Machoa JD 2008. Fish, wildlife, and human nutrition in tropical forests: A fat gap? Interciencia 33: 3, 186-193.

Sirén A, Tuomisto H \& Navarrete H 2013. Mapping environmental variation in lowland Amazonian rainforests using remote sensing and floristic data. International Journal of Remote Sensing 34: 5, 1561-1575. http://dx.doi.org/10.1080/01431161 .2012 .723148 .

Sponsel LE 1992. The environmental history of Amazonia: Natural and human disturbances, and the ecological transition. In Steen HK \& Tucker RP (Eds). Changing tropical forests: Historical perspectives on today's challenges in Central \& South America, 233-251. Forest History Society / IUFRO Forest History Group.
Spruce R 1996. Notas de un botánico en el Amazonas y en los Andes. Abya-Yala, Quito.

Stanfield ME 1998. Red Rubber, Bleeding Trees: Violence, Slavery, and Empire in Northwest Amazonia, 1850-1933. University of New Mexico Press.

Steward JH \& Metraux A 1948. Tribes of the Peruvian and Ecuadorian montaña. In Steward JH \& Metraux A (Eds). Handbook of South American Indians, 535-656. Vol. 3. Smithsonian Institution, Bureau of American Ethnology, Washington, DC.

Stirling MW 1938. Historical and ethnographical material on the Jivaro Indians. Washington, DC.

Stoner KE, Riba-Hernández P, Vulinec K \& Lambert JE 2007. The role of mammals in creating and modifying seedshadows in tropical forests and some possible consequences of their elimination. Biotropica 39, 316-327. http://dx.doi.org/10.1111/j.1744-7429.2007.00292.x.

Taylor AC 1986. La evolución demográfica de las poblaciones indígenas de la Alta Amazonia del siglo XVI al XX. Cultura 8:507-518.

Terborgh J, Nuñez-Iturri G, Pitman N, Cornejo-Valverde $\mathrm{FH}$, Alvarez $\mathrm{P}$, Swamy $\mathrm{V}$, Pringle EG \& Paine CET 2008. Tree recruitment in an empty forest. Ecology 89: 6, 1757-1768. http://dx.doi.org/10.1890/07-0479.1.

Tobar-Donoso J 1960. Historiadores y cronistas de las misiones. Jose M. Cajica, Mexico.

Un ex-Cronista Misionero 1946. Vivir de los indígenas misionados desde antaño. El Oriente Dominicano 160, 135-139.

Vargas JM 1931. Impresiones de un viaje a Canelos. El Oriente Dominicano 23, 161-168.

Vargas JM 1976. Aportes para la Historia de Macas, 44, 82. Mundo Shuar, Sucua.

deVernazza C 1849. Viaje practicado desde el Callao hasta las misiones de las dos tribus de infieles Záparos y Givaros. Imprenta de Justo Montoya, Lima.

Villavicencio M 1858. Geografia de la República del Ecuador. R. Craigshead, New York.

Weng C, Bush MB \& Athens JS 2002. Holocene climate change and hydrarch succession in lowland Amazonian Ecuador. Review of Palaeobotany and Palynology 120: 1, 73-90. http://dx.doi.org/10.1016/S0034-6667(01)00148-8.

Whittaker R 2005. The mapmaker's wife: A true tale of love, murder, and survival in the Amazon. Bantam Books, London.

Wright J, Hernandéz A \& Condit R 2007. The Bushmeat Harvest Alters Seedling Banks by Favoring Lianas, Large Seeds, and Seeds Dispersed by Bats, Birds, and Wind. Biotropica 39, 363-371. http:// dx.doi.org/10.1111/j.1744-7429.2007.00289.x.

Yost J \& Kelley PM 1983. Shotguns, blowguns, and spears: the analysis of technological efficiency. In Hames RB \& Vickers WT (Eds). Adaptive responses of native Amazonians, 189-224. Academic Press, New York. 